\title{
GIS risk analysis of a first-degree seismic zone: Kaynaşı (Turkey)
}

\author{
Hanifi Tokgöz ${ }^{1}$, Hüseyin Bayraktar ${ }^{2}$ \\ ${ }^{1}$ Civil Engineering, Faculty of Technology, Gazi University, Ankara, TURKEY \\ ${ }^{2}$ Architecture and City Planning Department, Kaynaşlı Vocational School, Düzce University, 81900 Düzce, TURKEY
}

\begin{tabular}{l}
\hline Article Info \\
\hline Article history: \\
Received Jun 6, 2018 \\
Revised Oct 16, 2018 \\
Accepted Oct 19, 2018 \\
\hline
\end{tabular}

\section{Keyword:}

Geographic information

system

Settlement suitability

Disaster

Street screening

\begin{abstract}
This study aimed to analyze the land survey maps and existing data to determine the vulnerable areas of the Kaynaşl districts at risk in terms of natural disaster, as Kaynaşlı is located in a first-degree seismic zone. This three-phase study analyzed geological-geotechnical survey reports via the geographic information system (GIS) and applied them to Kaynaşl1 Municipality in Düzce Province (Turkey). First, a non- digital raster suitability map based on a 2005 Kaynaşlı Municipality report was digitized via ArcGIS and used to conduct natural disaster risk analyses of Kaynaşl1. The 2112 buildings covered by the suitability map were then scanned and inventory information generated for each. Finally, using ArcGIS software, the digitized inventory information was superimposed on the suitability map. In Kaynasli, a total 2112 buildings were examined via street screening and their risk status was identified in terms of the terrain. Disaster and risk ratios were calculated and vulnerable areas were pinpointed. All the information obtained from the results of the analyses was shared with the local authorities. According to the physical inventory information, a sustainable data bank was created with the purpose of facilitating the necessary measures for disaster preparedness to be taken by the local authorities in Kaynaşl1. The model of this Kaynaşlı natural disaster risk study could be applied in other communities to assist in identifying vulnerable settlement areas.
\end{abstract}

\section{Corresponding Author:}

Hüseyin Bayraktar,

Architecture and City Planning Department,

Kaynaşlı Vocational School Duzce University, 81900 Düzce, TURKEY.

Email: h.byrktr979@gmail.com

\section{Introduction}

Experience and observations worldwide have shown that disaster management and the creation of disastersensitive communities could be achieved by effective institutional structuring, information sharing, developing education and awareness, planning risk reduction activities, and encouraging further research. Disaster prevention and preparedness are of great importance in the creation of disaster awareness in the population.

The basic steps taken against natural disaster risks include hazard analysis, damage vulnerability assessments, identification of geo-environmental and socio-economic factors, and risk assessment with the subsequent generation of risk maps as an outcome [1]. In Bantul, Indonesia, earthquake mitigation studies have identified suitable areas for land usage by using geographic information systems (GISs) and remote sensing methods [2]. Thus, correct solutions can be generated by providing sustainable cooperation and sharing knowledge and skills within a given system in order to reduce the damage and losses caused by natural disasters [3]. A 
positive outcome and successful application of disaster management and risk mitigation can be achieved by ensuring public participation [4].

Turkey experiences frequent natural disasters due to its geological, topographic, and climatic characteristics. These disasters, and in particular earthquakes, cause heavy loss of life and property. According to the earthquake zone map of Turkey, $92 \%$ of the land is in an earthquake region and $95 \%$ of the population lives in earthquake risk areas; therefore, this reality necessitates being prepared for disasters at any moment [5]. Raising social awareness of ways to prevent natural events such as earthquakes from turning into disasters, along with ensuring the suitability of physical structures in residential areas and giving priority to risk reduction efforts, may lead to expectations of minimizing disaster damage [6]. In this context, studies using GIS are increasingly being carried out in order to reduce disaster risks.

During the preparatory processes, applications of GIS methods can include identifying building damage likely to occur during seismic hazards [7], conducting analyses of flooding areas [8], and creating a map inventory of earthquake-triggered landslide areas [9]. In one example of this application, the ArcGIS program of GIS software was used for the modeling of low-risk and high-risk populations in the event of an earthquake disaster in China [10]. With the Geographic Information System, classifications can be made to the land or the surrounding area. As a result of the classifications made, flood and land use can be analyzed easily [11].

Turkey to take part in the earthquake zone is a country that should be prepared against earthquakes. For example, Turkey's largest city in İstanbul scientific and technical work is done for the expected major earthquake [12]. The aim of the present study was to reduce earthquake risks in terms of structural damage and to determine necessary preparedness measures by utilizing GIS methods. For this purpose, GIS disaster risk analyses of Kaynaşl1 were conducted and the results obtained from the analyses and support for disaster preparation studies were shared with the Kaynaşlı Municipal authorities. Furthermore, this study model can be applied in other situations where populations are vulnerable to disaster risks.

\section{Seismicity of Kaynaşlı}

Kaynaşlı Municipality, a subdivision of Düzce Province (Fig. 1) is located in a first-degree seismic zone. Kaynaşlı suffered serious casualties when hit by the earthquake of 12 November 1999. This earthquake occurred as a result of the movement of the Düzce fault line in an east-west direction along the Akyazi-Bolu tunnel, which is parallel to the North Anatolian Fault (NAF) line. It was understood that the westernmost part of the 30-km long segment of the Düzce Fault was fractured during the 17 August 1999 earthquake, in which primarily the 40-km long eastern part of the line was ruptured [13].

The 12 November 1999 Düzce earthquake, at a magnitude of 7.2 and depth of $14 \mathrm{~km}$, lasted for 33 seconds. During the earthquake, 316 people lost their lives and 543 eventually escaped with injuries. In this earthquake, $72 \%$ of the buildings in Kaynaşl1 were damaged [14].

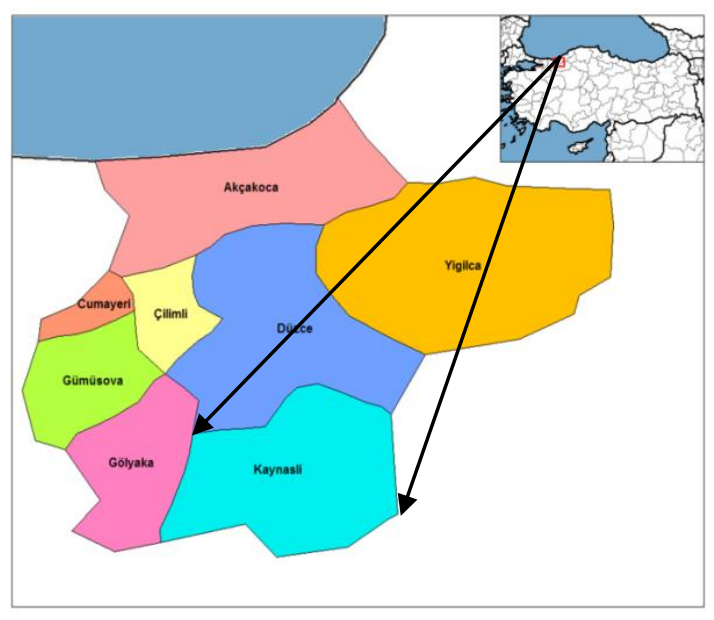

Figure 1. Düzce-Kaynaşlı study area

According to the Earthquake Assessment Study of the Ministry of Environment and Urban Planning dated 21 December 1999, most of the devastation seen as a result of the 12 November earthquake occurred in the 
Merkez District of Kaynaşl1 (Fig. 2). The total damage assessment study of the Ministry showed that 840 of the 1457 heavily damaged or demolished buildings were located in the Merkez District [15].

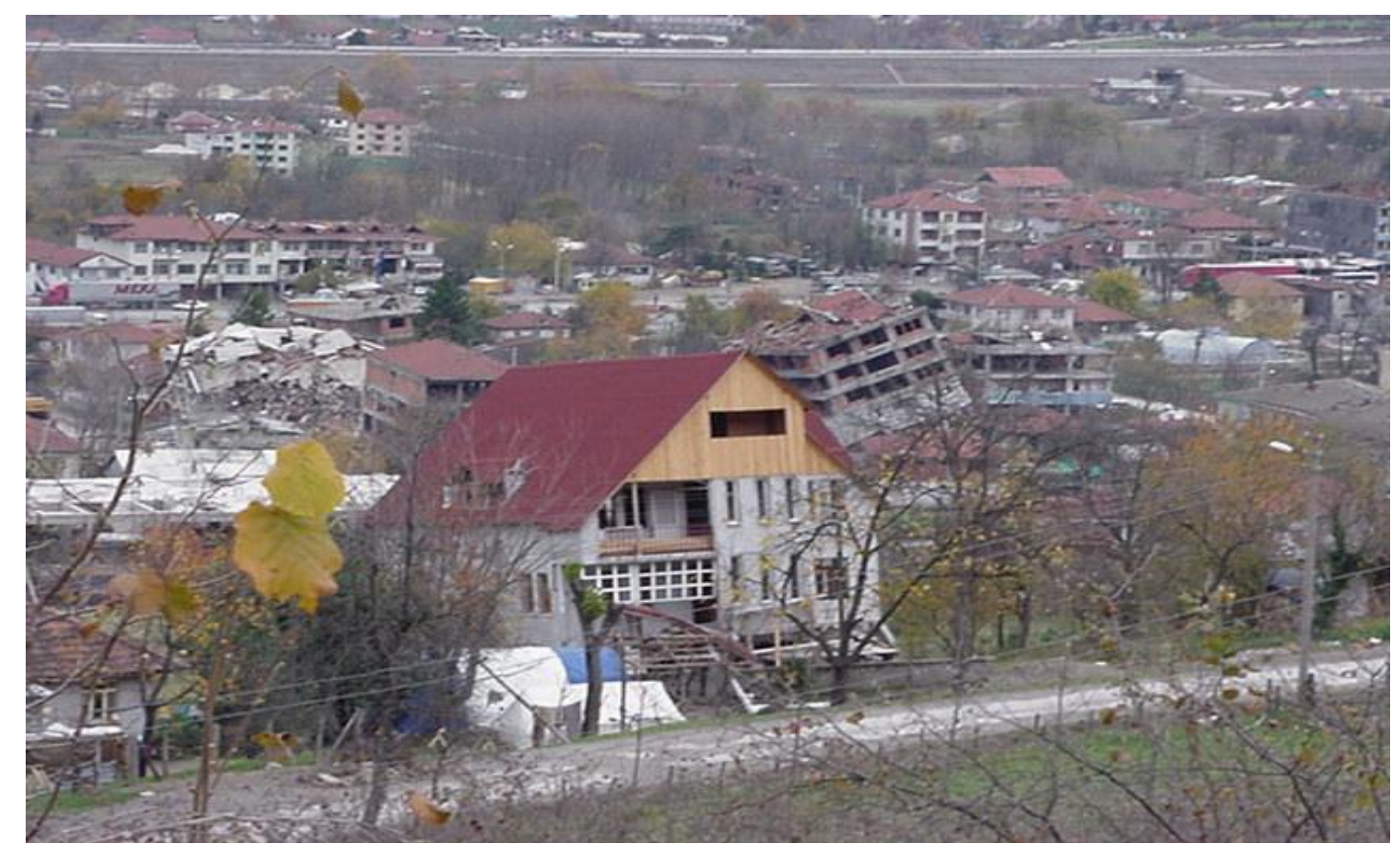

Figure 2. Destruction in Merkez District, Kaynaşl1, after the 12 November 1999 earthquake [14]

Figure 2 shows the heavy destruction that occurred during the devastating Kaynaşl1 earthquake. Some of the buildings were completely destroyed, while others were left leaning. Most of the collapsed structures consisted of high-rise buildings. Since the earthquake, the number of floors has been restricted to three as per the implemented reconstruction plan, and except for certain districts, detached (discrete) structures are now mandatory.

\section{Methodology}

For this study, first, the raster suitability maps in the geological-geotechnical survey reports prepared by the ZETA engineering project [16] were digitized using the ArcGIS program. The street screening method was used in the creation of the building inventory. The street screening procedure developed by Sucuoğlu (2007) [17] is a fast method of providing information about the strength and ability of buildings to withstand earthquakes by evaluating the negative parameters and assigning earthquake scores to the buildings according to these evaluations. In this way, it is possible to classify the surveyed buildings as high risk or low risk. In the study, the building information obtained via street screening was entered into the ArcGIS database and a risk map was created (Fig. 3). 


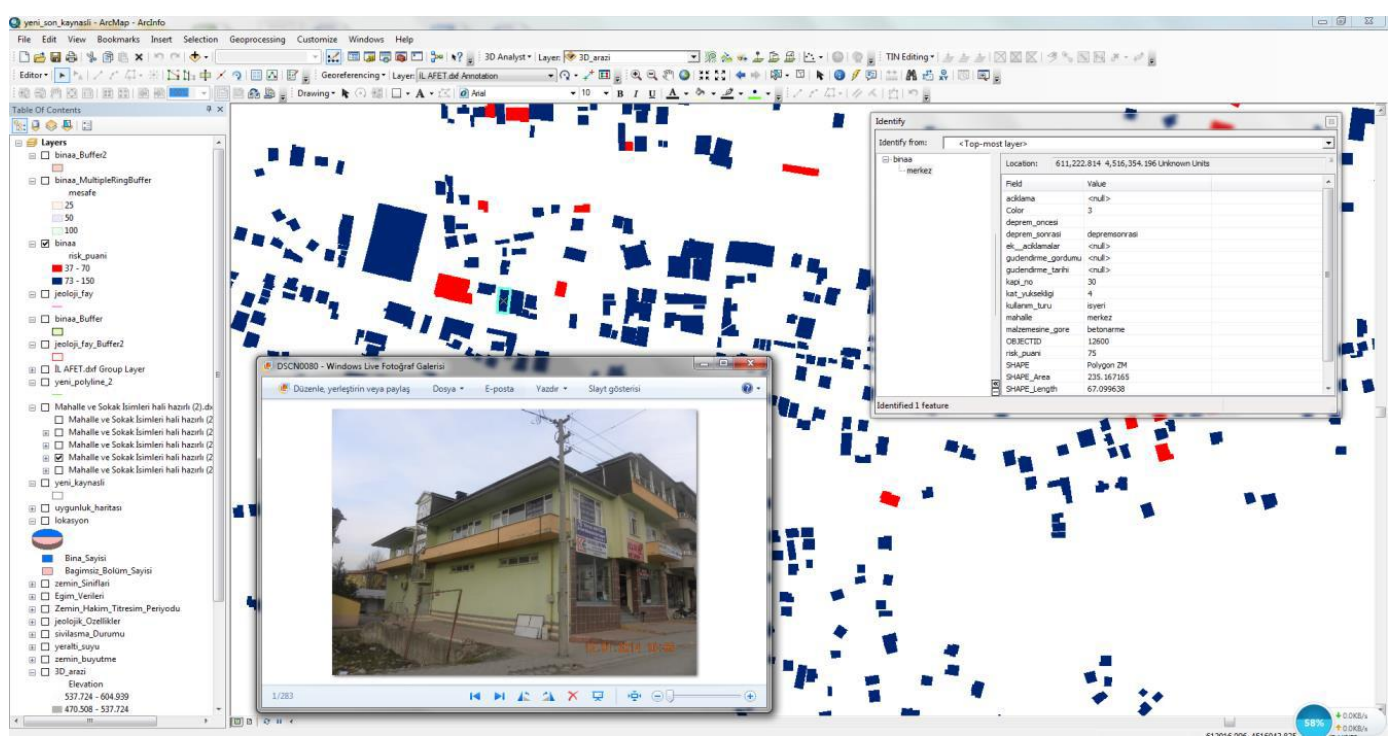

Figure 3. Building information obtained by street screening transferred to the ArcGIS database

The number of high-risk and low-risk structures was determined using the results of the earthquake building scores. At the same time, the number of people living in high-risk structures was found. The number of buildings and people at risk can be used as a base for developing the capacity for earthquake preparedness.

\subsection{Street screening method and building earthquake scores}

The street screening method is a fast technique whereby the risk status of a building can be found by observing its exterior for 10 minutes. The survey form used in the method was filled out for each building and the building earthquake score was thus obtained. In the evaluation of the buildings it was emphasized to the technical staff that they should pay careful attention to the survey form. The survey forms were completed separately for reinforced concrete, masonry and composite building types (Table 1).

Table 1. Survey forms [18]

Form 1: Street Information (to be completed by the Team Leader)

\begin{tabular}{|l|l|}
\hline Street Name & \\
\hline Neighborhood & \\
\hline District & \multicolumn{2}{|c|}{ East: } \\
\hline Geographical Coordinate 1 & North: \\
\hline Geographical Coordinate 2 & North : East: \\
\hline Velocity Zone & I $\square \quad \square \quad$ II $\square$ \\
\hline Note: Geographical coordinates will be taken at both ends of the street. \\
\hline
\end{tabular}

Form 2: General Building Information

House No.: $\square \quad$ Reinforced Concrete: $\square \quad$ Masonry: $\square \quad$ Composite:

Note: Form 3 will be used if the building type is reinforced concrete and Form 4 for masonry and composite types.

Form 3: Reinforced Concrete Building Information

\begin{tabular}{|l|lccc|}
\hline No. of Floors (Including basement) & & & & \\
\hline Soft Floors & No $\square$ & Yes $\square$ & & \\
\hline Heaviness & No $\square$ & Yes $\square$ & & \\
\hline Visible Quality & Good $\square$ & Moderate $\square$ & Bad $\square$ \\
\hline Short Columns & No $\square$ & Yes $\square$ & & \\
\hline Collision Effect & No $\square$ & Yes $\square$ & & \\
\hline Peak / Slope Effect & No $\square$ & Yes $\square$ & & \\
\hline
\end{tabular}

Form 4: Masonry and Composite Building Information

No. of Floors (Including basement) 


\begin{tabular}{|l|lcc|}
\hline Visible Quality & Good $\square$ & Moderate $\square \quad$ Bad $\square$ \\
\hline Amount of Wall Clearance & Low $\square$ & Moderate $\square \quad$ High $\square$ \\
\hline Wall Spacing & Regular $\square$ & Somewhat Regular $\quad \square$ Irregular $\square$ \\
\hline Collision Effect & No $\square$ & Yes $\square$ \\
\hline
\end{tabular}

After the questionnaire forms were completed, the building earthquake score was determined for each building according to the calculation tables. The calculation tables for reinforced concrete buildings are presented in Table 2 and for masonry and composite structures in Table 3.

Table 2. Calculation table for 1-7 storey reinforced concrete buildings [18]

\begin{tabular}{|l|l|l|l|l|l|l|l|l|l|}
\hline $\begin{array}{l}\text { No. of } \\
\text { Floors }\end{array}$ & $\begin{array}{l}\text { Velocity Zone I } \\
\text { PGV>60 }\end{array}$ & $\begin{array}{l}\text { Velocity Zone II } \\
40<\text { PGV }<60\end{array}$ & $\begin{array}{l}\text { Velocity Zone } \\
\text { III PGV<40 }\end{array}$ & $\begin{array}{l}\text { Soft } \\
\text { Floors }\end{array}$ & $\begin{array}{l}\text { Heavi- } \\
\text { ness }\end{array}$ & $\begin{array}{l}\text { Visible } \\
\text { Quality }\end{array}$ & $\begin{array}{l}\text { Short } \\
\text { Columns }\end{array}$ & $\begin{array}{l}\text { Collision } \\
\text { Effect }\end{array}$ & $\begin{array}{l}\text { Peak/Slope } \\
\text { Effect }\end{array}$ \\
\hline 1,2 & 100 & 130 & 150 & 0 & 0 & -10 & -5 & 0 & 0 \\
\hline 3 & 90 & 120 & 140 & -10 & -5 & -10 & -5 & -2 & 0 \\
\hline 4 & 75 & 100 & 120 & -15 & -10 & -10 & -5 & -3 & -2 \\
\hline 5 & 65 & 85 & 100 & -20 & -10 & -10 & -5 & -3 & -2 \\
\hline 7 & 60 & 80 & 90 & -20 & -10 & -10 & -5 & -3 & -2 \\
\hline
\end{tabular}

In Table 2, the PGV (peak ground velocity) is divided into three separate velocity zones. In the low ground classes the PGV, i.e., the rate of advancement in the seismic zone, is high, whereas in the case of sound ground, the PGV is low (Sucuoğlu, 2007). In the study, low ground classes Z4 and Z3 were taken respectively as Velocity Zone I (PGV > $60 \mathrm{~cm} / \mathrm{s})$ and Velocity Zone II (PGV $40<\mathrm{PGV}<60 \mathrm{~cm} / \mathrm{s})$. The more sound ground classes of Z1 and Z2, respectively, were taken as Velocity Zone III (PGV $<40 \mathrm{~cm} / \mathrm{s}$ ).

The six different negativity parameters (soft floors, heaviness, visible quality, short columns, collision effect, and peak / slope effect) in Table 2 were rated according to the number of floors. The building earthquake score for reinforced concrete buildings was calculated as follows:

Building Earthquake Score $=($ velocity zone score $)-\sum_{1}^{5}($ negativity parameters $) \times($ negation score $)$

Table 3 was used for masonry and composite buildings and includes the three velocity zones.

The velocity zones were selected according to the ground classes applied to the same reinforced concrete buildings. Velocity Zones II and III were on loose ground, while Velocity Zone I was on sound ground. The other four negativity parameters (visible quality, amount of wall clearance, wall spacing, and collision effect) were scored according to the floor height and survey evaluation of the building being inspected.

Table 3. Calculation table for 1-5 storey masonry and composite buildings [18]

\begin{tabular}{|l|l|l|l|l|l|l|l|}
\hline $\begin{array}{l}\text { No. of } \\
\text { Floors }\end{array}$ & $\begin{array}{l}\text { Velocity Zone } \\
\text { I PGV }>60\end{array}$ & $\begin{array}{l}\text { Velocity Zone II } \\
40<\text { PGV }<60\end{array}$ & $\begin{array}{l}\text { Velocity Zone III } \\
\text { PGV<40 }\end{array}$ & $\begin{array}{l}\text { Visible } \\
\text { Quality }\end{array}$ & $\begin{array}{l}\text { Amount of } \\
\text { Wall } \\
\text { Clearance }\end{array}$ & Wall Spacing & $\begin{array}{l}\text { Collision } \\
\text { Effect }\end{array}$ \\
\hline 1,2 & 100 & 130 & 150 & -10 & -5 & -2 & -5 \\
\hline 3 & 85 & 110 & 125 & -10 & -5 & -5 & -3 \\
\hline 4 & 70 & 90 & 110 & -10 & -5 & -5 & -5 \\
\hline 5 & 50 & 60 & 70 & -10 & -5 & -5 & -5 \\
\hline
\end{tabular}

According to the survey forms for masonry and composite buildings, the buildings were rated and the building earthquake score was calculated with the following formula:

(Earthquake building score calculation for masonry and composite buildings)

Building Earthquake score $=($ velocity zone score $)-\sum_{1}^{4}($ negativity parameters $) \times($ negation score $)$ 


\subsection{High- and low-risk buildings according to building earthquake scores}

Inventory information was taken according to the Kaynaşli Municipality 2112 building survey form. The buildings examined comprised around $90 \%$ of all the residences of the settlement. The reliability of the study results was increased by the high percentage of buildings examined. Building earthquake scores varied between 1 and 150 points. Using this method can help those who work on risk limits to determine low- or high-risk buildings. When the building earthquake score rises, the risk ratio decreases; however, when it falls, the risk ratio increases. In the study, the risk limit was determined as 70 points. In other words, buildings with a building earthquake score of less than 70 were identified as high-risk, whereas buildings with 70 points or more were identified as low-risk. Accordingly, the high-risk building rates were determined in the seven districts where the study was conducted (Fig. 4).

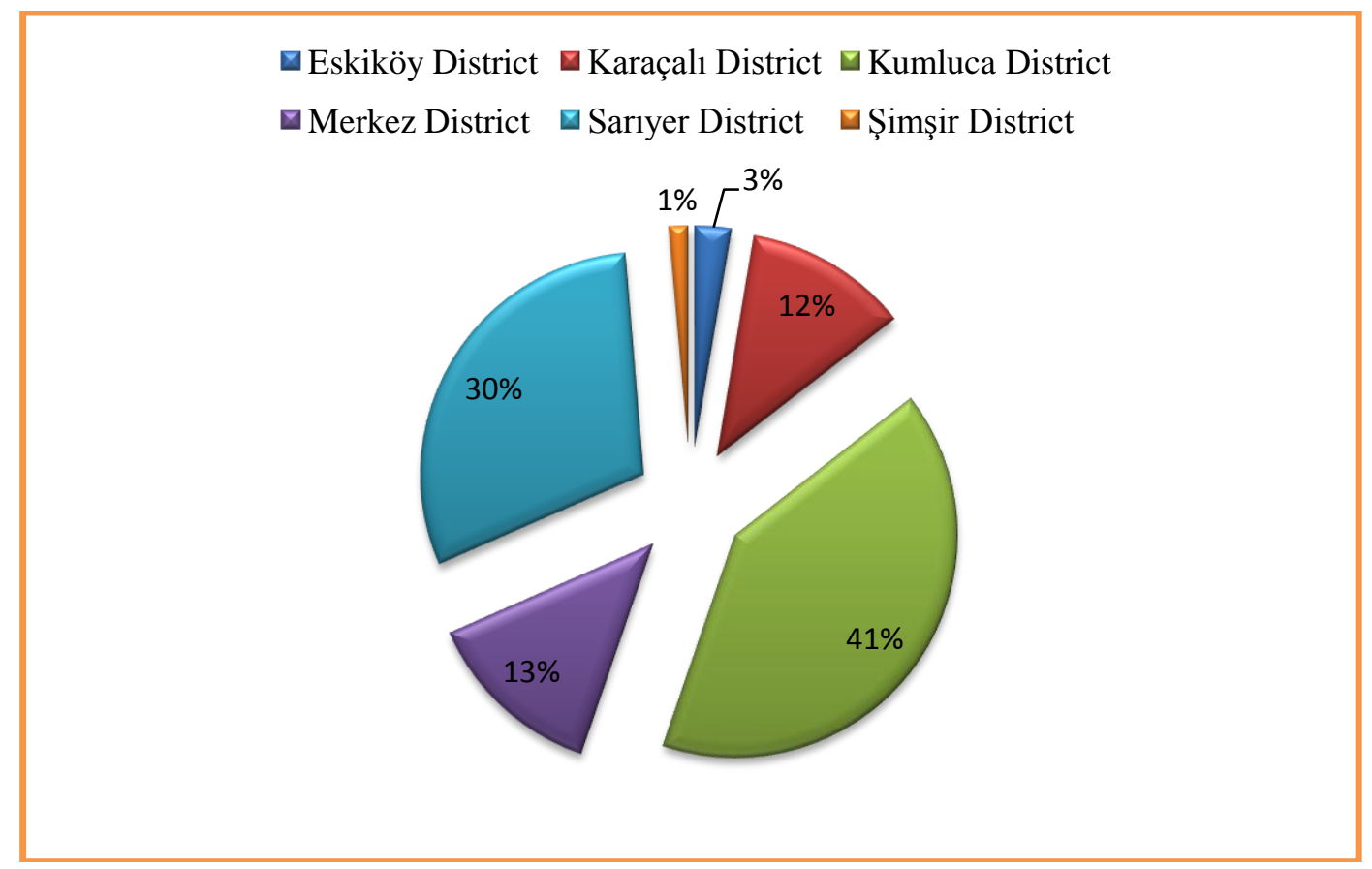

Figure 4. High-risk building rates according to district

According to the building earthquake scores, the greatest proportion of high-risk buildings (41\%) was found in Kumluca District. The district determined to have the lowest proportion of high-risk buildings (1\%) was Şimşir. The increased risk levels of the districts may have been determined by the pre-earthquake concentration of the buildings. Especially in the area of Şimşir, low-level (1-2-storey) houses were common and construction after the earthquake adhered to technical guidelines, thus reducing the risk ratio. According to the number of floors and number of flats of those buildings determined as high-risk by their earthquake scores, the numbers of people at risk were found. Based on the knowledge that an average family in Turkey consists of four people according to TurkStat data, four people were calculated per flat. Consequently, a total of 76 high-risk buildings were found according to the risk scores, and the number of persons at risk in these buildings was determined to be 1028 .

\subsection{Suitability map regions}

On the map, three natural disaster risk areas were located: a fault line (with a 20 -m buffer zone on each side), a landslide zone, and a flood zone (with a 10-m buffer zone on either side). On the suitability map, a total of eight regions were identified: SA (suitable areas), UA (unsuitable areas), PA1 (Precautionary Area 1), PA2 (Precautionary Area 2), PA3 (Precautionary Area 3), PA4 (Precautionary Area 4), PA5 (Precautionary Area 5), and PA6 (Precautionary Area 6). Buildings in the suitable areas do not bear any risk in terms of location, whereas buildings in the unsuitable areas are at risk in terms of placement. The precautionary areas are suitable for settlement if the appropriate action recommended by the report is taken regarding construction of buildings. 


\subsection{Suitability criteria}

The General Geological Plan and Geological-Geotechnical and Microzonation Survey Circular from the Directorate of Disaster Affairs [19], outlines detailed preliminary studies and definitions relating to SAs, UAs and PAs, using the following definitions:

Suitable Areas (SAs): Within the study area, except for earthquake situations, these do not bear any natural disaster hazard potential, any geological or geotechnical features or any engineering problems that could affect settlement suitability; these areas should be considered suitable for building construction with no further action needed.

Precautionary Areas (PAs): Within the study area, due to natural disaster hazards and/or geologicalgeotechnical properties, specific measures need to be taken that may affect settlement suitability in these areas before and/or during construction. The details of recommended measures, their reasons and precautions are given in the subsections.

Unsuitable Areas (UAs): Within the study area, due to natural disaster hazards and/or geotechnical problems, laws and similar reasons, or for economic or technical reasons, these are unsuitable areas. Therefore, they should not be considered as construction sites for any purpose, even if appropriate measures are taken. Explanations for designating these areas as UAs are clearly stated in the subsections.

After the conversion of the suitability map into numerical data, a data inventory was made of the construction dates (pre- and post-21 November 1999 earthquake) of the 2112 buildings surveyed by field application within the boundaries of the suitability map of Kaynaşl1. The building information was then transferred to the ArcGIS database and overlaid with the digitized suitability map. In this way, the area of the suitability map in which each building was located was determined according to the addresses, and the current situation of the settlement was evaluated in terms of risk (Fig. 5).

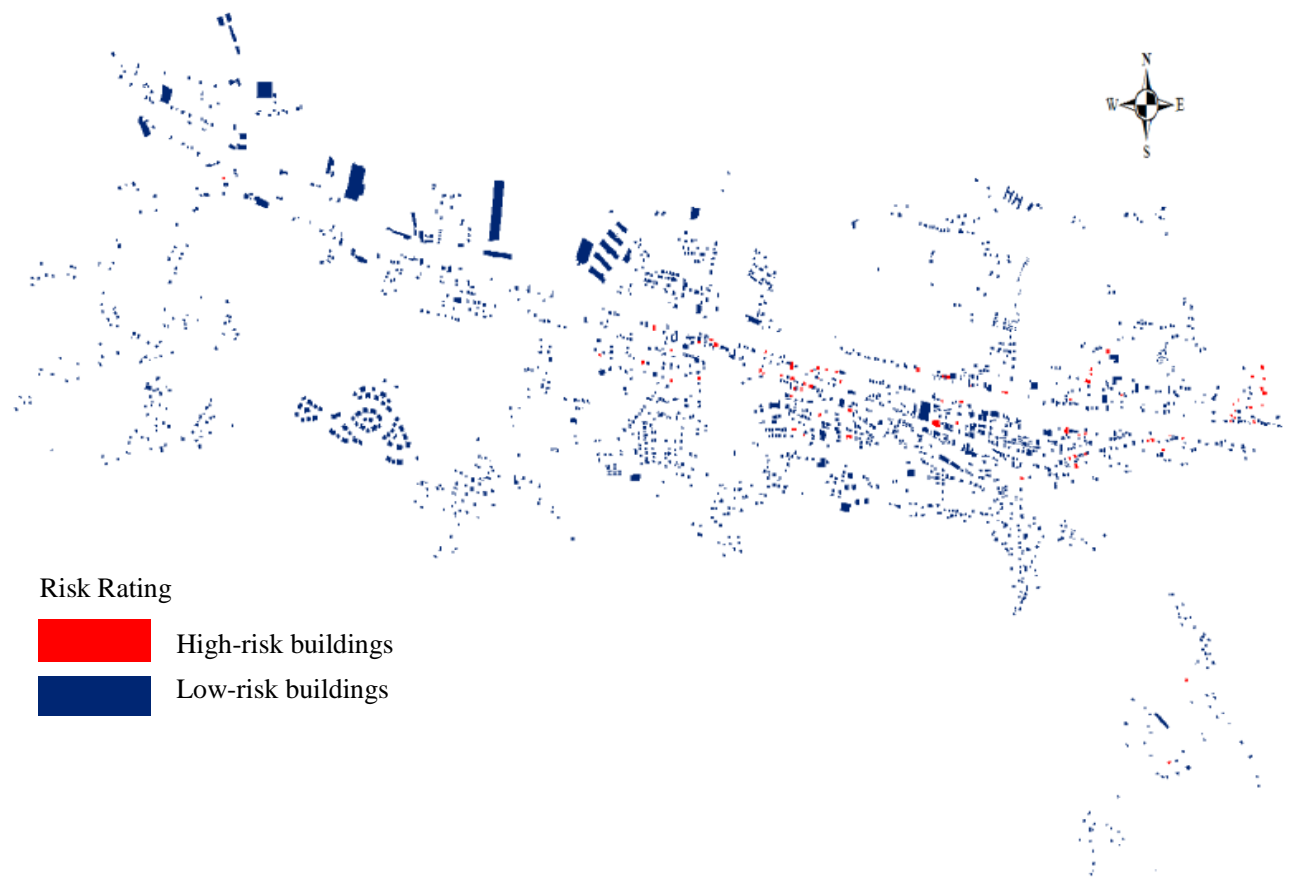

Figure 5. Risk map according to building earthquake scores obtained via street screening

\subsection{Building inventory and data collection}

After conversion of the suitability map into digital data, 2112 buildings in Kaynaşl1 within the suitability map boundaries were examined and processed with their inventory data and construction dates (pre- or postearthquake - 12 November 1999). Later, the building information was superimposed onto the digitized suitability map and transferred to the database using ArcGIS software. Thus, it was possible to determine the zone in which each building belonged on the suitability map according to the address, and the buildings could 
then be assessed in terms of risks. In this way, the location information and number of the buildings in unsuitable areas were compiled. The numbers of the buildings located in each suitability zone according to pre- and post-earthquake construction dates are given in Table 4.

Table 4. Distribution of buildings on the suitability map according to construction date

\begin{tabular}{lllllllllll}
\hline & \multicolumn{7}{c}{ Suitability Zones } \\
\cline { 2 - 5 } & SA & PA1 & PA2 & PA3 & PA4 & PA5 & PA6 & UA \\
$\begin{array}{l}\text { Number of buildings constructed } \\
\text { before the 12 November }\end{array}$ & 1999 & 130 & 13 & 140 & 23 & 226 & 145 & 148 & 18 \\
Earthquake & & & & & & & & \\
$\begin{array}{l}\text { Number of buildings constructed } \\
\text { after the 12 November }\end{array}$ & 269 & 32 & 267 & 24 & 345 & 158 & 133 & 41 \\
$\begin{array}{l}\text { Earthquake } \\
\begin{array}{l}\text { Total }\end{array}\end{array}$ & 399 & 45 & 407 & 47 & 571 & 303 & 281 & 59
\end{tabular}

\section{Kaynaşlı: Structural analysis}

There are seven districts in Kaynaşlı: Şimşir, Çele, Karaçalı, Merkez, Sarıyer, Kumluca and Eskiköy. According to data obtained from Kaynaşl1 Municipality, there are a total of 2211 buildings in these districts (Fig. 6). Of these buildings, 2112 were within the scope of the suitability study and their inventory data were obtained and analyzed in the ArcGIS program.

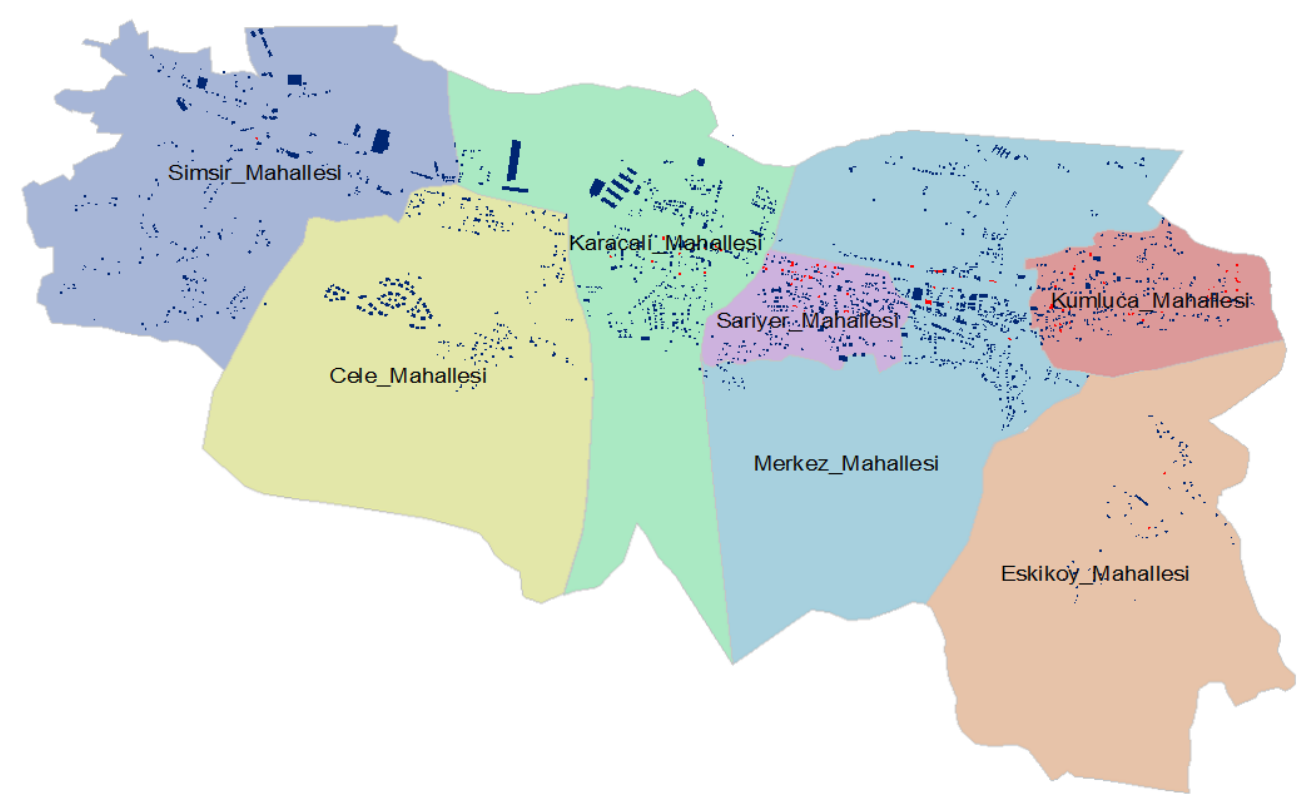

Figure 6. Kaynaşlı districts and the distribution of buildings within them

The pre-earthquake and post-earthquake distribution of buildings in all the districts of Kaynaşl1 are illustrated graphically in Figure 7, which shows that the majority of pre-earthquake buildings were constructed in Karaçal1 (237) and the majority constructed post-earthquake were in Merkez. The reason for the existence of many pre-earthquake buildings in Karaçalı is that fewer buildings there were damaged during the earthquake. When Karaçalı was structurally analyzed, it was seen that most of the buildings had a garden layout structure (discrete layout structure) and were built in the traditional style, having only one or two floors. Therefore, the 
earthquake damage risk was low. However, in Merkez, the buildings of four or five floors were in adjacent layout and generally built in non-compliance with proper construction techniques and thus, had increased risk of damage in terms of earthquake suitability. As a result, during the 12 November earthquake, the greatest numbers of heavily damaged or destroyed buildings were located in the Merkez district of Kaynaşli.

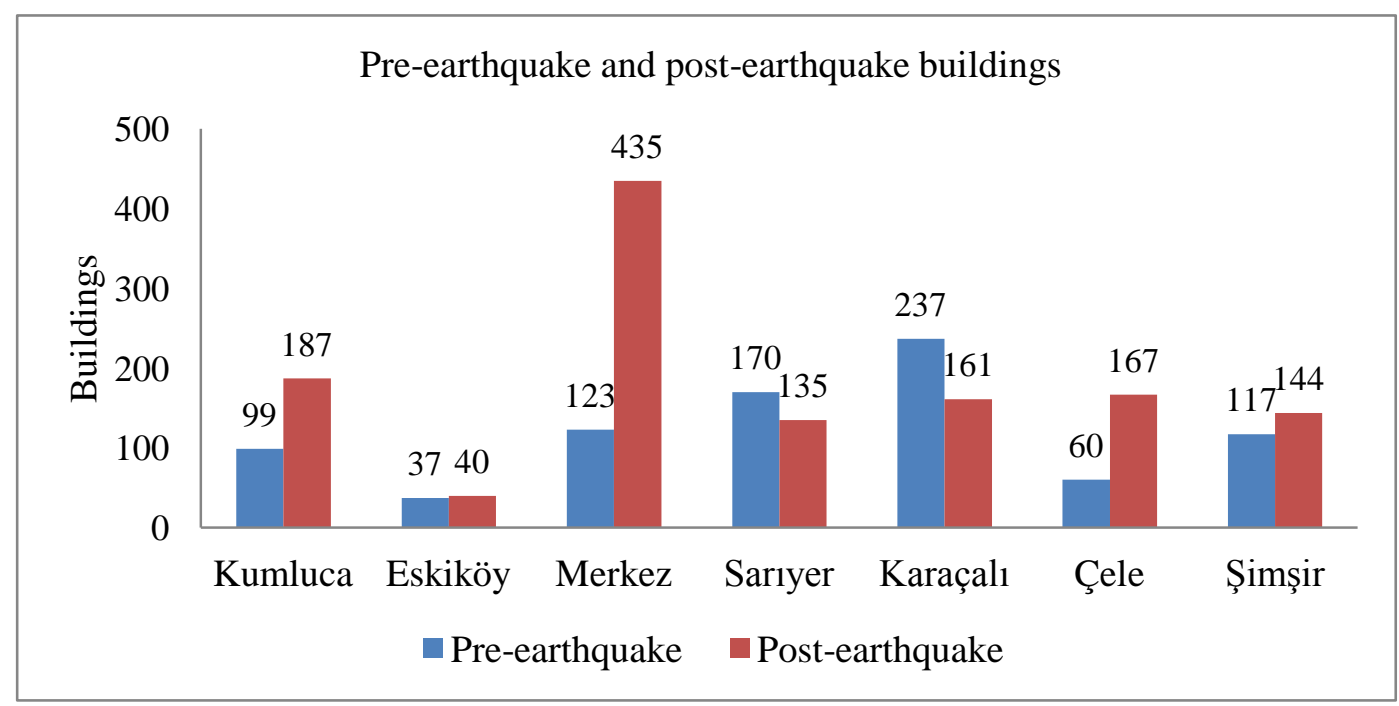

Figure 7. Distribution of pre- and post-earthquake buildings in the Kaynaşlı districts

\section{1. Şimşir}

Şimşir is located in the west of Kaynaşl1, partially bordering the upper part of Çele, with which it bears a resemblance as regards the form of the land, which is steep and hilly. The altitude of the district varies between 130 and $300 \mathrm{~m}$. It is a very large district, with one part located in a flat region dissected by the D-100 highway and another portion lying on the fault line.

When the building structures were examined according to their date of construction, the pre-earthquake and post-earthquake building rates were somewhat similar, with $44.83 \%$ (117) built pre-earthquake and $55.17 \%$ (144) post-earthquake.

In Şimşir, a total of 18 buildings are located in a suitable area and seven in an unsuitable area. The remaining buildings are located in Precautionary areas. Local authorities should conduct detailed studies of the seven buildings located in unsuitable areas, and they should be evaluated for either demolishment or strengthening reinforcement.

\section{2. Çele}

In Çele, a total of 227 buildings were examined. Most of the buildings were constructed post-earthquake. The increased number of post-earthquake buildings is due to the presence of permanent residences (59 buildings) constructed by the Ministry of Environment and Urban Planning in 2004 for the citizens whose buildings were destroyed in the 12 November earthquake, with approximately 550 people presently living in them.

An examination of the number of pre-earthquake and post-earthquake buildings in Çele showed that after the earthquake, 167 buildings were constructed, while only 60 were built before the earthquake. The area is suitable for settlement; therefore, post-earthquake building numbers $(73.57 \%)$ are higher than those of preearthquake buildings. Approximately $26 \%$ (59) of the post-earthquake buildings comprise permanent housing. In Çele, post-earthquake building construction increased due to the availability of suitable areas, thus boosting the dependability of Çele in terms of settlement potential. This was corroborated by survey results showing that $61 \%$ of residential buildings were constructed in these suitable areas. A detailed study should be carried out concerning the 15 buildings located in unsuitable areas. 


\subsection{Karaçalı}

Karaçalı is situated close to the town center in a flat area, and 398 (81\%) of the buildings in the district were examined. According to the Ministry of Environment and Urban Planning Damage Assessment Report dated 21 December 1999, 143 buildings were destroyed or heavily damaged, 11 moderately damaged, 29 lightly damaged and 308 undamaged in Karaçalı after the November 12 earthquake.

The buildings in Karaçalı are constructed with gardens and are generally two-storey, traditional-type houses. Therefore, in the November 12 earthquake, there was not a great amount of building damage, so the number of pre-earthquake buildings in Karaçalı (237) is greater than the number of post-earthquake buildings constructed in the district. According to the suitability map, 16 buildings were found to be constructed in suitable areas and six located in unsuitable areas. Most of the buildings in the district are located in precautionary areas. Performing a structurally-detailed data collection survey relating to the six buildings located in unsuitable areas would be an appropriate measure.

\subsection{Sarlyer}

Within the Sariyer survey, 305 buildings were examined. Sarıyer is the smallest among the districts, but in terms of residency, it is an active district near to the town center. According to the abovementioned Ministry report, 125 buildings were destroyed or heavily damaged, 67 moderately damaged, 63 lightly damaged and 179 undamaged buildings in Saryer post-earthquake. According to the suitability map, there are no unsuitable areas located in Saryer, so 69 buildings were found to be in suitable areas, while the remaining buildings are located in precautionary areas. Despite the lack of unsuitable areas in the district, the number of destroyed or heavily damaged buildings was high after the November 12 earthquake. This demonstrates that a number of the buildings were likely in non-compliance with the construction techniques and codes required by the geological features.

\subsection{Merkez}

In Merkez, located in the center of Kaynaşl1, $98 \%$ of the 558 buildings in the neighborhood were examined within the survey context. Merkez is the most crowded district, as evidenced by the population and the number of buildings.

According to the Ministry report, 840 destroyed or heavily damaged buildings were identified in Merkez postearthquake. Merkez suffered the most severe damage compared to the other districts. In Merkez, the preearthquake buildings were generally four- or five-storey high-rises lacking suitable ground conditions and constructed according to an adjacent system without respect to proper construction techniques or building codes. Therefore, the earthquake damage ratio was higher. Consequently, the number of buildings constructed after the earthquake was greater due to the destruction of most of the pre-earthquake buildings. The number of pre-earthquake buildings was 123 , while the number constructed post-earthquake was 435 . This situation is an indication that new structures had replaced destroyed buildings. The most significant reason for Merkez as a popular residential choice is the presence of public institutions and facilities located in this district as part of the town center.

Whereas 54 buildings were found to be in suitable areas, 26 buildings were situated in unsuitable areas. As a part of Merkez is positioned in areas classed as unstable ground and due to the heavy population concentration in this district, it is essential that further detailed examinations and research studies be conducted for this district.

\subsection{Kumluca}

Kumluca is located near the center of the town along the D-100 highway, and consists mostly of flat terrain. The number of buildings analyzed within this study concept was 286 .

According to the Ministry report, 191 buildings were destroyed or heavily damaged, 28 moderately damaged, 14 lightly damaged and 16 undamaged post-earthquake in Kumluca. The earthquake-damaged building rate was high in this district. Therefore, the number of buildings constructed post-earthquake was almost double those constructed pre-earthquake. According to the suitability map, 30 buildings were located in suitable areas, while two were located in unsuitable areas. 


\subsection{Eskiköy}

Compared to the other districts, Eskiköy has the highest elevation, located at altitudes ranging between 450 and $600 \mathrm{~m}$. Eskiköy is situated on firm ground and is 3-4 km from the town center. It has the lowest number of earthquake-damaged buildings. The number of buildings examined in the study context was $77,71 \%$ of which were analyzed. Eskiköy buildings are scattered over rugged terrain.

Eskiköy is classed as a safe place for settlement in terms of earthquakes. The ground structure is rigid and the buildings are in traditional style, mostly having only one or two storeys. Thus, during the earthquake, this district suffered the least amount of damage. Based on the suitability map, 74 buildings were situated in suitable areas, and three in unsuitable areas. Eskiköy, due to the presence of low-rise buildings on firm ground, was shown to be a safe place for residence.

\section{Results and Discussion}

On the suitability map (Fig. 6) there are three probable natural disaster risk areas shown for the residential districts. The first one is the $6.5 \mathrm{~km}$ North Anatolian Fault Line passing through central Kaynaşl1 and extending along in an east-west direction. Geological and geotechnical surveys have reported the fault line. The fault line and the $20 \mathrm{~m}$ on either side designated as a buffer zone have been evaluated as an unsuitable area on the suitability map. The second area evaluated as an unsuitable area is the flooding area, comprising the 10-m buffer zones on either side of Asar Creek, which passes through and extends to the northwest of the residential areas in Kaynaşl1. The third is the landslide area southeast of the residential districts. These three risk areas were evaluated as unsuitable on the suitability map. During the field applications of the study, the information obtained on the buildings was compared by overlaying the building data in suitability terms using the ArcGIS program. Buildings on fault lines, in flood risk areas, and in landslide areas were evaluated as being in disaster risk areas. In Table 5, which was created based on the suitability map, the distribution of buildings in all districts can be seen.

Table 5. Distribution of buildings in all districts (from the suitability map)

\begin{tabular}{|l|l|l|l|l|l|l|l|l|}
\hline Districts & SA & PA1 & PA2 & PA3 & PA4 & PA5 & PA6 & UA \\
\hline Çele & 138 & - & - & 17 & - & - & 57 & 15 \\
\hline Merkez & 54 & 45 & 157 & - & 206 & 47 & 23 & 26 \\
\hline Şimşir & 18 & - & 28 & 30 & - & 90 & 88 & 7 \\
\hline Karaçalı & 16 & - & 60 & - & 107 & 108 & 101 & 6 \\
\hline Kumluca & 30 & - & 162 & - & 80 & - & 12 & 2 \\
\hline Sarıyer & 69 & - & - & - & 178 & 58 & - & - \\
\hline Eskiköy & 74 & - & - & - & - & - & - & 3 \\
\hline
\end{tabular}

Çele, with 138 buildings, was the district having the highest number of buildings lying in suitable areas. The district with the lowest number of buildings situated in suitable areas was Kumluca, with two buildings. Merkez was the district with the highest number of buildings found in unsuitable areas, with 26 buildings, while in Sariyer no buildings were located in unsuitable areas. The precautionary areas remaining outside of the suitable and unsuitable areas (PA1, PA2, PA3, PA4, PA5, and PA6) were classified as presenting no problems for building construction, provided that measures outlined in the report regarding building foundations and drainage are carried out. A total of 1654 buildings were found to be present in the precautionary areas of all districts.

The Kaynaşl1 building inventory information as per the suitability map (Fig. 8) was determined according to field work. Of the buildings placed on the suitability map, 78\% (1654 buildings) are located in precautionary areas, whereas 19\% (399 buildings) are in suitable areas. 


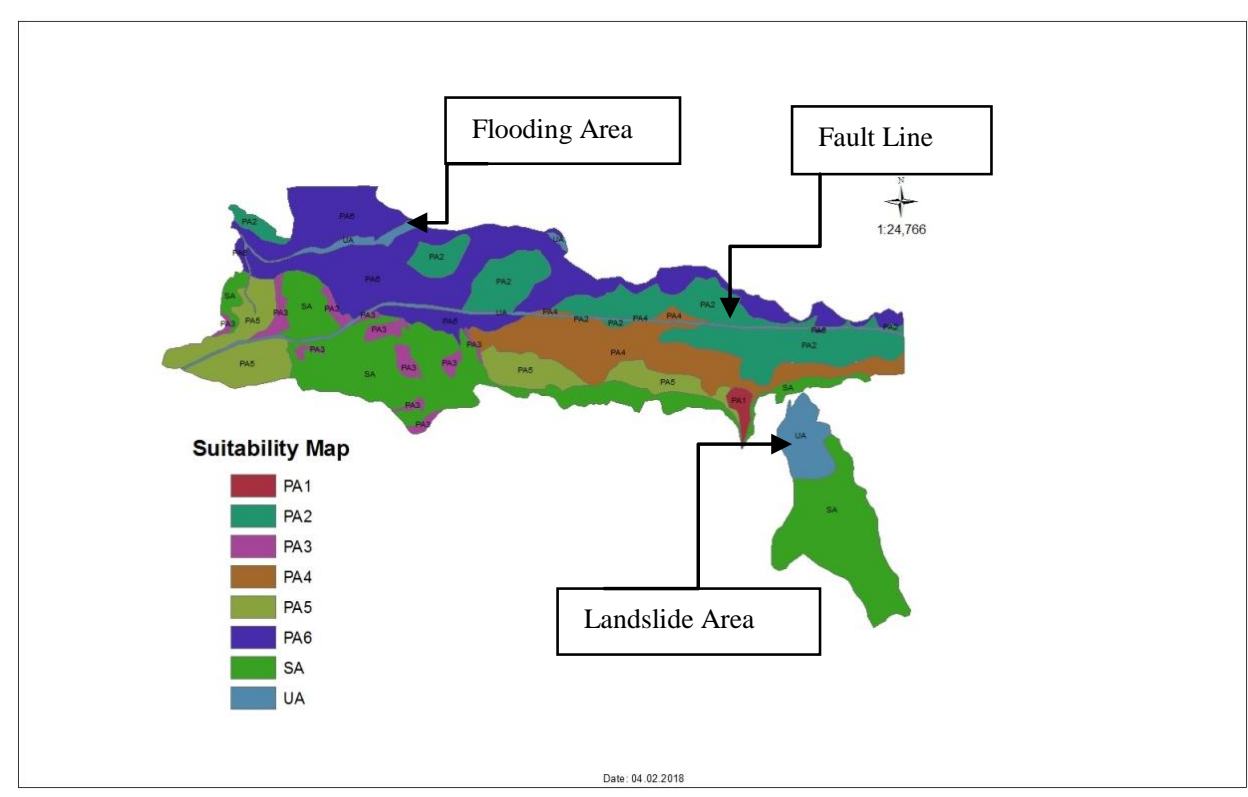

Figure 8. Digitized version of the raster suitability map (SA: suitable areas, UA: unsuitable areas, PA1PA6: Precautionary Areas1-6)

The 59 buildings located in unsuitable areas account for $3 \%$ of the total number of buildings, with 18 of these constructed pre-earthquake and 41 post-earthquake. This situation indicates that post-earthquake building construction was carried out in unsuitable areas without referencing the suitability maps.

The buildings located in unsuitable areas can be more vulnerable to disaster risks. The 18 buildings constructed in unsuitable areas before the 17 August 1999 Marmara and 12 November 1999 Düzce earthquakes were subsequently exposed to these seismic events, yet they continue to be used. The prior exposure of these buildings to two large earthquakes and the fact that they are not in accordance with the new construction requirements have targeted them as high risk. Necessary measures must be taken by the local authorities in such cases to minimize the risk and prevent further damage after a future earthquake.

\section{Conclusion}

As a result of the study, raster (non-digital) suitability maps from the geological-geotechnical survey report of 2005 conducted by the ZETA Company were digitized in the ArcGIS program and entered into a database. This map was subsequently used as a base to ensure that settlement suitability could be determined as quickly as possible in order to make a disaster preparedness analysis of the pre-existing and newly constructed buildings in the residential areas. Field surveys were conducted in Kaynaşlı by inspecting the premises, and the data of 2112 buildings were collected via the street screening method according to their pre- or postearthquake construction dates. These data were transferred to the ArcGIS database and analyzed based on the suitability map. All the information obtained from the results of the analyses was shared with the local authorities. According to the physical inventory information, a sustainable data bank was created with the purpose of facilitating the necessary measures for disaster preparedness to be taken by the local authorities in Kaynaşl1.

\section{References}

[1] Xiaoyan DU and Xiaofei L, "Conceptual Model on Regional Natural Disaster Risk Assessment," International Symposium on Safety Science and Technology: pp. 96-100, 2012.

[2] Haryanaa IK, Fikriyaha VN, Yulianti NV, “Application of Remote Sensing and Geographic Information System for settlement land use classification planning in Bantul based on Earthquake Disaster Mitigation (Case Study: Bantul earthquake, May 27th 2006)," The 3rd International Conference on Sustainable Future for Human Security: pp. 434-443, 2013. 
[3] Kadıŏlu M, "Modern, Bütünleşik Afet Yönetimin Temel İlkeleri”. Basic Principles of Modern Disaster Mitigation (Modern, Bütünleşik Afet Yönetimin Temel İlkeleri Afet Zararlarını Azaltmanın Temel İlkeleri). JICA Türkiye Ofisi Yayınlart: 1-34 (in Turkish), 2008.

[4] JICA-Japan International Cooperation Agency (Japonya Uluslararası İşbirliği Ajansı) "Türkiye'de Doğal Afetler Konulu Ülke Strateji Raporu 121," National Strategy Report on Natural Disasters in Turkey No. 121. (in Turkish), 2004.

[5] AFAD-Republic of Turkey Prime Ministry AFAD Earthquake Division Headquarters (Türkiye Cumhuriyeti Başbakanlık AFAD Deprem Dairesi Başkanlığı) (2014) Earthquake-Related Technical Issues (Depremle İlgili Teknik Konular). http://www.deprem.gov.tr/?aspxerrorpath=/sarbis/Deprem/DepremNedir.aspx\#KONU9 (in Turkish) Accessed 30 June 2017

[6] Karanc1 AN, "The Importance of Psychology in Reducing Disaster Losses: Basic Principles of Disaster Mitigation," (Afet Zararlarını Azaltmada Psikolojinin Önemi: Afet Zararlarını Azaltmanın Temel İlkeleri). JICA Türkiye Ofisi Yayınları No. 2: pp. 51-58 (in Turkish), 2008.

[7] Irwansyah E and Hartati S, "Assessment of Building Damage Hazard Caused by Earthquake: Integration of FNN and GIS," International Conference on Future Information Engineering: pp. 196-202, 2014.

[8] Utamia S, Surjono S, Soemarno Bisri M, "Disaster Risk and Adaptation of Settlement along the River Brantas in the Context of Sustainable Development, Malang, Indonesia," 4th International Conference on Sustainable Future for Human Security: pp. 602-611, 2014.

[9] Xu C, "Preparation of earthquake-triggered landslide inventory maps using remote sensing and GIS technologies: Principles and case studies". Geoscience Frontiers: pp. 825-836, 2014.

[10] Liu H, Cui X, Yuan D, Wang Z, Jin J, Wang M, "Study of Earthquake Disaster Population Risk Based on GIS: A Case Study of Wenchuan Earthquake Region," 2nd International Conference on Challenges in Environmental Science and Computer Engineering (CESCE 2011) Procedia Environmental Sciences 11 (Part C): pp. 1084-1091, 2011.

[11] Öztürk M, Bolat İ, Gökyer E, Kara Ö. Land Use Suitability Classification for the Actual Agricultural Areas within the Bartın Stream Watershed of Turkey. Periodicals of Engineering and Natural Sciences, Vol. 5 No. 1 (2017) - Special Issue (Recent Topics in Environmental Science).

[12] Beyhan G, Keskinsezer A, Beyhan S. A comparative study on Soil Properties and Applications Review with EERA and NERA in İstanbul-MARMARAY Project between Kazlıçeşme to Sirkeci. Periodicals of Engineering and Natural Sciences, Vol. 5 No. 1 (2017) - Special Issue (Recent Topics in Environmental Science).

[13] MTA-General Directorate of Mining Technical Search [Maden Teknik Arama (MTA) Genel Müdürlüğü (2014) 12 November 1999 Düzce Earthquake (12 Kasım 1999 Düzce Depremi). http://www.mta.gov.tr/v3.0/bilgi-merkezi/12kasimduzce (in Turkish) Accessed 30 June 2017

[14] Republic of Turkey Kaynaşlı Governorate (Türkiye Cumhuriyeti Kaynaşlı Kaymakamlığı (1999), Kaynaşlı Crisis Management Center Archive (Kaynaşlı Kriz Yönetim Merkezi Arşivi). (in Turkish)

[15] Republic of Turkey Kaynaşlı Municipality (Türkiye Cumhuriyeti Kaynaşlı Belediyesi) (1989) Science Department Directorate Archives (Fen İşleri Müdürlüğü Arşivi). (in Turkish)

[16] ZETA Project Engineering Construction Limited Company (ZETA Proje Mühendislik İnşaat Limited Şirketi) Geological-Geotechnical Survey Report based on Revision and Supplementary Zoning Plan (Revize Imar ve Illave Imar Planina Esas Jeolojik-Jeoteknik Etüt Raporu). Ankara, pp. 114-123 (in Turkish), 2005.

[17] Sucuoğlu H, "A Screening Procedure for Seismic Risk Assessment in Urban Building Stocks," (Kentsel Yap1 Stoklarında Deprem Risklerinin Sokaktan Tarama Yöntemi İle Belirlenmesi), Sixth National Conference on Earthquake Engineering (6. Ulusal Deprem Mühendisliği Konferans1), İstanbul: pp. 267284, 2007.

[18] Bayındırlık ve İskan Bakanlığı, "Mevcut Yapıların İncelenmesi ve Yapı Denetimi Komisyonu Raporu," Deprem Şurasi, pp. 27-29, 2004.

[19] Ministry of Public Works and Settlement (Ministry of Environment and Urbanization) General Directorate of Disaster Affairs [Bayındırlık ve İskan Bakanlığı (Çevre ve Şehircilik Bakanlığı) Afet İşleri 
Genel Müdürlüğ̈̈] General Geological Plan, Geological-Geotechnical and Microzonation Survey Circular (Plana Esas Jeolojik, Jeolojik-Jeoteknik ve Mikrobölgeleme Etüt Genelgesi), 2008.

\section{BIBLIOGRAPHY OF AUTHORS}

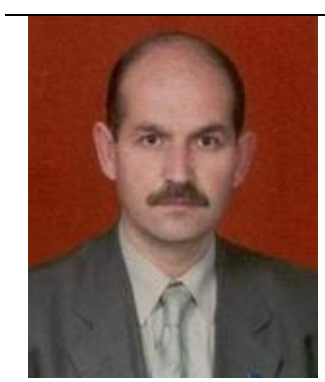

Hanifi Tokgöz received his undergraduate and graduate education from Gazi University Department of Building Education. He received his $\mathrm{PhD}$ degree from Çukurova University. He worked as a research assistant at Gazi University between 1985-1995. In 1996, he started to teach as a lecturer at Gazi University and still continues in the same position. Research areas include surveying, computer aided design, steel structures and wooden structures.

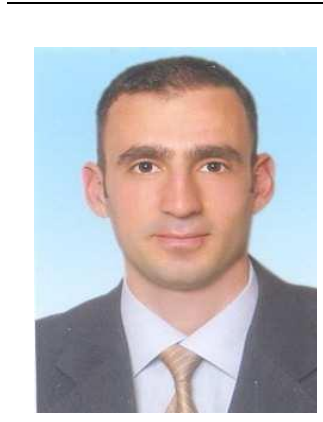

Hüseyin Bayraktar completed his undergraduate education at Gazi University, graduate education at Selçuk University and his doctorate education at Gazi University. He started to work as a teaching assistant at Düzce University in 2008-2014. From 2015 onwards, he continues to serve as a lecturer at the same university. Areas of work include disaster management, disaster risk assessment, building and geographic information systems. 